\title{
COPRAS Approach for Efficiency Assessment of R\&D Expenditures in Technology Transfer Process
}

\author{
Jelena Stankevičienè $\dot{1}^{1}$ Lidija Kraujalienè ${ }^{2}$ \\ Department of Finance Engineering, Faculty of Business Management, \\ Vilnius Gediminas Technical University, Vilnius, Lithuania \\ E-mails: ${ }^{j}$ jelena.stankeviciene@vgtu.lt (corresponding author); ${ }^{2}$ lidija.kraujaliene@vgtu.lt
}

Received 26 February 2017; accepted 11 April 2017

\begin{abstract}
Higher education institutions (HEI) performance results depends not only on successful innovative technology transfer (TT) activities and university-industry cooperation, but also on governance funding, distributed by the priority for certain research and development $(R \& D)$ fields. The purpose of this article is to propose a concept to assess the efficiency of R\&D funding by sector of performance in European countries. The main goal of the paper is to propose a concept to assess the efficiency of R\&D funding in European countries, provide insights, recommendations, and point out tendencies for the future improvement of European funding system for HEIs. Multicriteria ranking method COPRAS - an instrument for analysis and decision-making. The empirical research is based on Eurostat data for the period of 2005-2014. Expenditures on R\&D gives the fluent explication of European R\&D funding (investments) emphasizing the execution of innovation and TT activities at universities. The proposed assessment model allows comparing performance results and rank countries according the efficiency of research funding. Empirical results reveal that the comparatively higher efficiency of research expenditures is in the Northern European countries, Luxembourg and France. Latter tendency slowing to move forward and enhance performance results of HEIs, as well as countries' economic growth.
\end{abstract}

Keywords: HEI, R\&D, performance, COPRAS, technology transfer (TT).

JEL Classification: G32, O32, O34.

Conference topic: Contemporary Financial Management.

\section{Introduction}

Decision making methods helps to analyse the performance measures of higher education instituions (HEI), to show the direction improving technology transfer (TT) process. Huge research papers prove that the more governance investments the better TT results could be reached. Important point here is the R\&D fields which countries are selected as the priority to strengthen and develop innovative actitivites for the future.

This article is based on analysing European countries through comparing the data of R\&D expenditures by sector of performance. The purpose of this article is to propose a concept to assess the efficiency of R\&D funding by sector of performance in European countries, provide insights, recommendations, and point out tendencies for the future improvement of European funding system for HEIs.

European documents show the priority to invest for R\&D. "Europe 2020" document's one of the priority is to invest (public and private) into the R\&D - at least 3\% of GDP (European commission 2016). Latter need related with the demand to base economic development by knowledge, innovation and TT activities. In comparison, National Progress Programme for Lithuania for the period 2014-2020 is intending to reach R\&D funding - 1,9\% of GDP for Lithuania. Statistics Lithuania provides the total R\&D expenditure in Lithuania for 2015 - 0,9\% GDP, meanwhile for Europe this indicator is - 1,9\% GDP in 2015 (Statistics Lithuania 2016).

First of all, it should be seleted the method for analysis and decision-making. The empirical research is based on Eurostat data for the period of 2005-2014 (ten years) (Eurostat 2017).

The object of the research is - R\&D expenditures by sectors of performance, identified by Eurostat as the main sectors participating in R\&D activities (Eurostat 2017). In addition, sectors of performance are selected also on the base TT and innovation process, where are participating such parties as HEIs, business (also non-profit based) and government. It is important to evaluate $R \& D$ expenditures in every sector of performance to provide insights and recommendations to archieve better performance results.

(C) 2017 J. Stankevičienè, L. Kraujalienè. Published by VGTU Press. This is an open-access article distributed under the terms of the Creative Commons Attribution (CC BY 4.0) License, which permits unrestricted use, distribution, and reproduction in any medium, provided the original author and source are credited. 
Main research tasks:

- to create a data set of R\&D expenditures in TT process by sectors of performance for European countries;

- to develop approach to assess the efficiency of R\&D funding by sector of performance in European countries;

- to analyse performance results: R\&D expenditures, by sectors of performance and provide insights and recommendations.

This article is organized as follows. In the section of Performance indicators to explicit R\&D expenditures in TT process, we discuss chosen performance indicators for the research. Next section describes COPRAS approach. Later all 8 COPRAS steps (methodology of COPRAS) are explained for use. The concluding remarks are given in the section of Conclusions.

\section{Performance indicators to explicit $R \& D$ expenditures in TT process}

Performance indicators of R\&D expenditures in TT process are important to see the picture of different sectors with their investment to R\&D. The performance of innovation and technology transfer processes depends on the amount of investments for innovation activities. Therefore, we need a clear picture of investments from different sides: business, higher education, government, non-profit organizations. Efficiency assessment of R\&D expenditures in TT process encompasses European countries R\&D performance indicators ranking by the best results. Efficiency assessment in this paper performed in 4 different sectors of performance, identified in Eurostat database (Eurostat 2017):

- business enterprise sector;

- government sector;

- higher education sector;

- private non-profit sector.

All mentioned sectors and its parties (business, science or government institutions) are involved into the TT and innovation processes.

The research of this article involves such indicators as showed in Table 1.

Table 1. Performance indicators of R\&D expenditures in TT process (Source: compiled by authors according to Eurostat 2017)

\begin{tabular}{|c|c|c|c|c|}
\hline \multicolumn{5}{|c|}{ Indicators } \\
\hline $\begin{array}{l}\text { Intramural } R \& D \\
\text { expenditure (GERD) } \\
\text { (Euro per inhabitant) }\end{array}$ & $\begin{array}{l}\text { Intramural R\&D expenditure (GERD) } \\
\text { (Purchasing Power Standard (PPS) } \\
\text { per inhabitant at constant prices) }\end{array}$ & $\begin{array}{l}\text { Sector of fund- } \\
\text { All sectors (Euro } \\
\text { per inhabitant) }\end{array}$ & $\begin{array}{l}\text { Total R\&D ex- } \\
\text { penditure (Euro } \\
\text { per inhabitant) }\end{array}$ & $\begin{array}{l}\text { Total R\&D activity } \\
\text { (Euro per inhabit- } \\
\text { ant) }\end{array}$ \\
\hline
\end{tabular}

The same performance indicators, mentioned in Table 1, were evaluated in every 4 sector of performace. In total, calculation was performed for 20 performance indicators in 4 sectors, analysing 28 European countries.

\section{COPRAS approach to assess the efficiency of expenditures for R\&D}

In contemporary world, quantitative multi-criteria decision-making (MCDM) methods have been used as a rule for comparative evaluation of technological and economic or social processes, and also to determine the best alternative within a number of options and rank those alternatives by their performance results (Podvezko 2011).

The main concept of quantitative evaluation methods is converting the values of criteria, which are characterizing a certain process, and weights of criteria into a one dimension - the criterion of the method. In the case of maximizing criteria, the best is the largest value, and in another case - during calculation of minimizing criteria, the best is the smallest value. Performance indicators of criteria and their units are also different. All alternatives are comparing between each other, and ranking in accordance with calculated values of certain criterion (Podvezko 2011).

For the analysis we choose the data from Eurostat database in the period of [2005-2014] (Eurostat 2017). Every analyzed sector of performance invests different part of theirs budget for R\&D processes. Investments contribute to the innovation and economic growth as a result. It is necessary to see the investments measures and compare them between each others. Therefore, all performance indicators should be putted on one platform. For latter purpose we should choose one of decision-making methods.

What is the main aspect of use MCDM methods? MCDM methods need the use of precise determined data. This means that should be precisely determined performance ratings of alternatives and weights of criterion (Popovic et al. 2012).

During the selection of sector of performance for R\&D investnments, decision-making persons usually make a choice between different available alternative sectors of performance based on certain attribute. What is multi-criteria decision-making problem in this article? The answer is - the selection of sector of performance for R\&D investment 
can be considered as a problem. Often multi-criteria decision-making (MCDM) methods usually proposed to use for selection of the most appropriate sector (Popovic et al. 2012).

The scientists from Vilnius Gediminas Technical University (VGTU) - Zavadskas, Kaklauskas and Sarka in 1994 were introduced the complex proportional multi-criteria evaluation method, called - COPRAS (in other words: COmplex PRoportional ASsessment). This method allows quantitative multi-criteria evaluation of minimizing and maximizing chosen complex indicators of various criteria. A number of auhors are used COPRAS (and its extention) or other MCDM methods in theirs research papers (Zavadskas, Kaklauskas 1996; Kaklauskas et al. 2006; Ginevicius 2008; Zavadskas et al. 2008a, 2008b, 2008c; Turskis et al. 2009; Kaklauskas et al. 2010; Kracka et al. 2010; Tupenaite et al. 2010; Chatterjee et al. 2011; Tavana et al. 2013; Aghdaie et al. 2013; Zavadskas et al. 2014a, 2014b; Ghorabaee et al. 2014; Hashemkhani Zolfani, Bahrami 2014; Pitchipoo et al. 2014; Bausys et al. 2015; Nguyen et al. 2015; Liou et al. 2016; Mulliner et al. 2016; Xue et al. 2016; Mousavi-Nasab, Sotoudeh-Anvari 2017; Koçak et al. 2017; Rivera et al. 2017; Rezazadeh et al. 2017; Sen et al. 2017; Zolfani et al. 2017).

To assess the efficiency of R\&D funding by sector of performance in European countries is possible applying decision - making method - COPRAS, which allows normalizing data and grouping them by the priority. This method was chosen as the one of the quite simple and clearly understandable multicriteria method to use and analyze the funding "levels" of R\&D. The research results are leading with insights and recommendations for the future to fund R\&D activities in one or another sector of performance, with the goal - to put the country into the higher economic level.

For applying COPRAS method we should to form the data decision matrix $D$ of the criteria ( $j$-criterion), which are describing the alternatives $i_{j}(j=1,2, \ldots, n)$ compared between each other. We need statistical data or expert estimates data, also the weights (significances) $\omega_{i}(i=1,2, \ldots, m)$ of criteria, where $n$ is the number of criteria and $m$ is the number of the alternatives compared.

\section{Methodology of COPRAS}

COPRAS multiple-criteria decision-making method was introduced by Zavadskas and Kaklauskas (Podvezko 2011). Let's see the approach to assess the efficiency of R\&D funding by sector of performance in European countries step by step. This approach could be used also to assess any other performance results and prioritize them by the best.

\section{COPRAS Step 1. Data decision matrix formation}

To solve certain problems in the business - science area, first of all it should be formed decision-making matrix from the data, as in this case, Eurostat. Latter matrix is constructed by the formula 1 (Organ, Yalcin 2016):

$$
D=\frac{A_{1}}{A_{2}} A_{3}\left[\begin{array}{ccccc}
x_{11} & x_{11} & x_{13} & \cdot & x_{1 n} \\
x_{21} & x_{22} & x_{23} & \cdot & x_{2 n} \\
x_{31} & x_{32} & x_{33} & \cdot & x_{3 n} \\
\cdot & \cdot & \cdot & \cdot & \cdot \\
x_{m 1} & x_{m 2} & x_{m 3} & \cdot & x_{m n}
\end{array}\right],
$$

where: $D$ - decision-making matrix, $A$ - selected European countries for research, $x$ - the data from Eurostat database for every country in certain year, $m$ - the number of alternatives, $n$ - the number of chosen criteria.

\section{COPRAS Step 2. Decision-making matrix normalization}

Second step is needed to convert performance indicators to normalized dimensions values and later use them for the calculation. COPRAS method normalization formula is presented in formula 2 (Organ, Yalcın 2016):

$$
\tilde{x}_{i j}=\frac{x_{i j}}{\sum_{i=1}^{m} x_{i j}},
$$

where: $x_{i j}-i$-th alternhative performance of the $j$-th criterion; $\tilde{x}_{i j}$ - the normalized value of $j$-th criterion; $m$ - the number of alternatives. 


\section{COPRAS Step 3. Defining of weighted normalized decision-making matrix}

Weighted normalized decision-making matrix is forming after the step of construction normalized decision-making matrix. The weighted normalized decision-making matrix is forming by the next formula 3 (Organ, Yalcin 2016):

$$
D^{\prime}=d_{i j}=x_{i j}^{*} * w_{j},
$$

where: $x_{i j}$-the performance of $i$-th alternative; $w_{j}$-weight of criterion.

\section{COPRAS Step 4. Maximizing and minimizing index calculation for every alternative}

This stage is intended for identifying which alternatives will be maximized and which - minimized. So, each alternative is categorized as minimizing and maximizing index. See the formulas 4 and 5 for that purposes (Organ, Yalcin 2016):

for maximizing index calculation: $\quad S_{i+}=\sum_{j=1}^{k} d_{i j}$, when $\mathrm{j}=1,2,3, \ldots, k$.

for minimizing index calculation: $S_{i-}=\sum_{j=k+1}^{n} d_{i j}$, when $\mathrm{j}=\mathrm{k}+1, \mathrm{k}+2, \ldots, n$.

\section{COPRAS Step 5. Relative weight's calculation for every alternative}

Relative weight's $Q_{i}$ calculation for $i$-th alternative is performed by the formula as follows (Organ, Yalcin 2016):

$$
Q_{i}=S_{+i}+\frac{\min _{i} S_{-i} \sum_{i=1}^{m} S_{-i}}{S_{-i} \sum_{i=1}^{m} \frac{\min _{i} S_{-i}}{S_{-i}}}
$$

\section{COPRAS Step 6. This step is intended to determine the priority order for each alternative}

The priority order is given based on the weight of each alternative; the results are distriuted by comparing alternatives weights between each other. The essense is that the higher rank has the alternative with the higher relative weight. This alternative with the highest weight is the most acceptable alternative in comparison with all rest (Organ, Yalcın 2016).

$$
A^{*}=\left\{A_{i} \mid \max _{i} Q_{i}\right\}
$$

where $A$ - the priority order of alternatives.

\section{COPRAS Step 7. Performance index calculation.}

Performance index calculation is performing by the formula 8 as showed below (Organ, Yalcın 2016):

$$
P_{i}=\frac{Q_{i}}{Q_{\max }} * 100 \%
$$

where $P_{i}$ - performance index of alternatives.

Alternative with 100 degree means the best one. The ranking of alternatives performed by the order from the bet one, to the worst (Organ, Yalcin 2016).

\section{COPRAS Step 8. Ultimate ranking of alternatives.}

This step is follows ater the calculation of performance index $P_{i}$ of alternatives. The aim of this step is to distribute the results of $P_{i}$ from the best to worst to make the conclusion and prepare final results of the research. 


\section{Empirical Results}

For deeper analysis to understand which 4 sectors: business, higher education, government, non-profit organizations are investing for R\&D the most, comparing selected European countries. Analysis incorporate the data which shows how much investments mentioned 4 sectors are investing in chosen one: if we analyse business sector, we see how much all 4 sectors invests to chosen business sector.

Empyrical results are described in order of chosen performance data in every year, starting from 2005 till 2014 (Eurostat 2017). It was selected 10 years range to see the better view while comparing investments results to R\&D taking 4 sectors implementing technology transfer and innovation processes in their activities.

Research is constructed of 28 chosen European countries (alternatives) and 5 performance indicators of R\&D expenditures in TT process (criteria), which are mentioned in Table 1 (Eurostat 2017):

- Intramural R\&D expenditure (GERD) (Euro per inhabitant).

- Intramural R\&D expenditure (GERD) (Purchasing Power Standard (PPS) per inhabitant at constant prices).

- Sector of fund - All sectors (Euro per inhabitant).

- Total R\&D expendi-ture (Euro per inhabitant).

- Total R\&D activity (Euro per inhabitant).

All steps from 1 to 8 were performed by proposed approach. Indicators were maximized for the research. Indicators weights were chosen equal, because the research was performed without qualitative expert's surveys. Therefore, when 5 indicators have the weigh of 1 , every indicator has the weight of $0,2(1: 5=0,2)$.

Table 2. COPRAS calculation results of sector 1 of performance: Business enterprise sector [2005-2014] (Source: compiled by authors)

\begin{tabular}{|c|c|c|}
\hline Country & Calculated results (average) & Rank \\
\hline Sweden & 200 & 1 \\
\hline Finland & 184 & 2 \\
\hline Luxembourg & 183 & 3 \\
\hline Denmark & 174 & 4 \\
\hline Austria & 138 & 5 \\
\hline Germany & 122 & 6 \\
\hline Belgium & 100 & 7 \\
\hline France & 89 & 8 \\
\hline Ireland & 84 & 9 \\
\hline Netherlands & 76 & 10 \\
\hline United Kingdom & 71 & 11 \\
\hline Slovenia & 49 & 12 \\
\hline Italy & 36 & 13 \\
\hline Spain & 33 & 14 \\
\hline Czech Republic & 25 & 15 \\
\hline Portugal & 21 & 16 \\
\hline Estonia & 19 & 17 \\
\hline Hungary & 14 & 18 \\
\hline Malta & 13 & 19 \\
\hline Croatia & 7 & 20 \\
\hline Slovakia & 6 & 21 \\
\hline Greece & 6 & 22 \\
\hline Poland & 5 & 23 \\
\hline Lithuania & 4 & 24 \\
\hline Latvia & 4 & 25 \\
\hline Cyprus & 4 & 26 \\
\hline Bulgaria & 3 & 27 \\
\hline Romania & 2 & 28 \\
\hline
\end{tabular}


As we see from the Table 2, the best results of investments to R\&D of business sector have these countries: Sweden, Finland, Luxembourg, Denmark, Austria and others. Lithuania is on the 24 place from 28.

The Table 3 shows that such countries as: Luxembourg, Germany, Finland, France and Netherlands are in TOP 5 of investors to R\&D of government sector. Lithuania is on the 24 place from 28 . Clear results we see in Table 4 of evaluating the biggest investors to R\&D for higher education sector. Countries, which invest the most: Denmark, Sweden, Finland, Netherlands and Austria. Lithuania is on the 19 place from 28.

Table 5 explicit analysis results of investors to R\&D for non-profit sector. Performance results showed that these countries invest to R\&D for non-profit sector the most: Portugal, Cyprus, United Kingdom, Italy and France. Lithuania is on the 24 place from 28. Covering all sectors to get general picture which European countries invest to R\&D the most for all 4 sectors, we get these results, that Finland, Luxembourg, Denmark, Sweden and France are investing to $\mathrm{R} \& \mathrm{D}$ the most. Lithuania is on the 22 place in total from 28.

Table 3. COPRAS calculation results of sector 2 of performance: Government sector [2005-2014] (Source: compiled by authors)

\begin{tabular}{|c|c|c|}
\hline Country & Calculated results (average) & Rank \\
\hline Luxembourg & 391 & 1 \\
\hline Germany & 212 & 2 \\
\hline Finland & 191 & 3 \\
\hline France & 175 & 4 \\
\hline Netherlands & 142 & 5 \\
\hline Slovenia & 106 & 6 \\
\hline Sweden & 104 & 7 \\
\hline Belgium & 100 & 8 \\
\hline Spain & 94 & 9 \\
\hline United Kingdom & 86 & 10 \\
\hline Austria & 82 & 11 \\
\hline Italy & 82 & 12 \\
\hline Czech Republic & 74 & 13 \\
\hline Denmark & 69 & 14 \\
\hline Ireland & 58 & 15 \\
\hline Hungary & 38 & 16 \\
\hline Croatia & 37 & 17 \\
\hline Poland & 35 & 18 \\
\hline Cyprus & 35 & 19 \\
\hline Slovakia & 35 & 20 \\
\hline Greece & 35 & 21 \\
\hline Estonia & 31 & 22 \\
\hline Portugal & 29 & 23 \\
\hline Lithuania & 29 & 24 \\
\hline Latvia & 24 & 25 \\
\hline Bulgaria & 19 & 26 \\
\hline Romania & 19 & 27 \\
\hline Malta & 10 & 28 \\
\hline
\end{tabular}

As we see, the best results in investments to R\&D belong to the most economically developed countries in Europe: Luxembourg, Germany, Finland, France and Netherlands. The worst results in this sector have Malta, Romania, Bulgaria, Latvia.

Let's see the picture of investing values for higher education sector in Table 4. 
Stankevičienè, J.; Kraujaliene, L. 2017. COPRAS approach for efficiency assessment of R\&D

expenditures in technology transfer process

Table 4. COPRAS calculation results of sector 3 of performance: Higher education sector [2005-2014] (Source: compiled by authors)

\begin{tabular}{|c|c|c|}
\hline Country & Calculated results (average) & Rank \\
\hline Denmark & 237 & 1 \\
\hline Sweden & 217 & 2 \\
\hline Finland & 162 & 3 \\
\hline Netherlands & 159 & 4 \\
\hline Austria & 156 & 5 \\
\hline Belgium & 100 & 6 \\
\hline Ireland & 100 & 7 \\
\hline Germany & 97 & 8 \\
\hline United Kingdom & 95 & 9 \\
\hline France & 90 & 10 \\
\hline Luxembourg & 70 & 11 \\
\hline Italy & 63 & 12 \\
\hline Spain & 54 & 13 \\
\hline Portugal & 51 & 14 \\
\hline Estonia & 45 & 15 \\
\hline Czech Republic & 31 & 16 \\
\hline Cyprus & 30 & 17 \\
\hline Slovenia & 29 & 18 \\
\hline Lithuania & 28 & 19 \\
\hline Greece & 25 & 20 \\
\hline Malta & 22 & 21 \\
\hline Latvia & 17 & 22 \\
\hline Croatia & 17 & 23 \\
\hline Hungary & 15 & 24 \\
\hline Poland & 14 & 25 \\
\hline Slovakia & 14 & 26 \\
\hline Romania & 4 & 27 \\
\hline Bulgaria & 2 & 28 \\
\hline
\end{tabular}

Higher education sector is one of the most important one to push countries to the higher level trough innovations. As we can see, the results from Table 4, such countires as Denmark, Sweden, Finland, Netherlands and Austria invest to R\&D for higher education sector the most. Northen countries are active in this activity. The lowest expenditures has Bulgaria, Romania, Slovakia, Poland and Hungary.

Table 5. COPRAS calculation results of sector 4 of performance: Private non-profit sector [2005-2014] (Source: compiled by authors)

\begin{tabular}{c|c|c}
\hline Country & Calculated results (average) & Rank \\
\hline Portugal & 286 & 1 \\
\hline Cyprus & 242 & 2 \\
\hline United Kingdom & 217 & 3 \\
\hline Italy & 204 & 4 \\
\hline France & 183 & 5 \\
\hline
\end{tabular}




\begin{tabular}{|c|c|c|}
\hline Country & Calculated results (average) & Rank \\
\hline Finland & 162 & 6 \\
\hline Denmark & 109 & 7 \\
\hline Belgium & 100 & 8 \\
\hline Austria & 82 & 9 \\
\hline Sweden & 60 & 10 \\
\hline Estonia & 53 & 11 \\
\hline Greece & 22 & 12 \\
\hline Czech Republic & 21 & 13 \\
\hline Spain & 10 & 14 \\
\hline Bulgaria & 5 & 15 \\
\hline Slovenia & 5 & 16 \\
\hline Poland & 5 & 17 \\
\hline Slovakia & 3 & 18 \\
\hline Romania & 3 & 19 \\
\hline Croatia & 1 & 20 \\
\hline Germany & 0 & 21 \\
\hline Ireland & 0 & 22 \\
\hline Latvia & 0 & 23 \\
\hline Lithuania & 0 & 24 \\
\hline Luxembourg & 0 & 25 \\
\hline Hungary & 0 & 26 \\
\hline Malta & 0 & 27 \\
\hline Netherlands & 0 & 28 \\
\hline
\end{tabular}

Portugal, Cyprus, United Kingdom, Italy and France take attention and investing for R\&D for private non-profit sector. Lithuania spends on R\&D much less money and it is on the rank 24. Strange, but the worst result for rivate non-profit sector shows Netherlands, when it seems it should be vice versa. On the other hand, if we compare the Netherlands performance results on investments to R\&D for higher education sector; in this case this country is in the TOP 5 from the best. It means, that this country more pay attention into the investments for higher education sector, and it is right step to turn country into the best archievements in technology transfer and innovation activities and its performance results.

Table 6. COPRAS calculation results of performance: All 4 sectors [2005-2014] (Source: compiled by authors)

\begin{tabular}{c|c|c}
\hline Country & Rank (average) & Group \\
\hline Finland & 1 & \multirow{2}{*}{1} \\
\hline Luxembourg & 2 & \\
\hline Denmark & 3 & \\
\hline Sweden & 4 & 2 \\
\hline France & 5 & \\
\hline United Kingdom & 6 & \\
\hline Austria & 7 & \\
\hline Germany & 8 &
\end{tabular}




\begin{tabular}{|c|c|c|}
\hline Country & Rank (average) & Group \\
\hline Belgium & 9 & \multirow{4}{*}{3} \\
\hline Portugal & 10 & \\
\hline Italy & 11 & \\
\hline Netherlands & 12 & \\
\hline Cyprus & 13 & \multirow{4}{*}{4} \\
\hline Ireland & 14 & \\
\hline Spain & 15 & \\
\hline Slovenia & 16 & \\
\hline Czech Republic & 17 & \multirow{4}{*}{5} \\
\hline Estonia & 18 & \\
\hline Greece & 19 & \\
\hline Hungary & 20 & \\
\hline Croatia & 21 & \multirow{4}{*}{6} \\
\hline Lithuania & 22 & \\
\hline Slovakia & 23 & \\
\hline Poland & 24 & \\
\hline Malta & 25 & \multirow{4}{*}{7} \\
\hline Latvia & 26 & \\
\hline Bulgaria & 27 & \\
\hline Romania & 28 & \\
\hline
\end{tabular}

Last Table 6 allowed seeing aprobated results and formulating the conclusion that COPRAS method allowed us to see the TOP countiries that pay attention and see the need of investing to R\&D. Calculation results distributed by 7 groups. The best investors to R\&D into all 4 analysed sectors are these countries from group 1: Finland, Luxembourg, Denmark and Sweden. Here we see three northen countries and Luxembourg. In group 2 are: France, United Kingdom, Austria, and Germany. Group 3 lead such countries as Belgium, Portugal, Italy and Netherlands. And if we carefully see all groups we see, that the most economically developed countries invests to R\&D the most. Lithuania is on the 22 place from 28.

\section{Conclusions}

It was formed decision-making matrix based on Eurostat data: R\&D expenditures in TT process by sectors of performance for European countries. There are a number of various decition-making methods to evaluate performance results, hovewer COPRAS method is quite easy in use and allows taking the multi-criteria indicators with different values putting them on the one platform, giving them certain weights and compare them giving the rank of performance. The advantage of COPRAS is that here are separately evaluating maximizing and minimizing criteria and its influence on the total evaluating result. COPRAS was suggested for the approach while Eurostat data was approbated using mentioned multicriteria decision-making method. The results showed, that this method is fully applicable to assess the efficiency of R\&D funding by sector of performance.

During analysis of Eurostat data in the range of 10 years: [2005-2014], COPRAS results showed, that the best performance results on R\&D investments into 4 sectors (business, higher education, government, non-profit) have these European countries (starting from the higher performance results) in TOP 10: Finland, Luxembourg, Denmark, Sweden, France, United Kingdom, Austria, and Germany. It shows that northern countries together with France, UK, Austria and Germany are investing for R\&D the most.

Northern countiries, as Sweden, Finland and Denmark are in the TOP 10, except government sector, where Denmark is in the TOP 14. However, in total results northern countries win before others.

After analyzing performance results, let us provide some results, insights and recommendations following.

Northern countries, and also Luxembourg, France, UK, Austria and Germany care about their countries from the deep understanding, that only through fostering TT and innovation activities, funding them, is the key to push the 
expenditures in technology transfer process

country on the higher level. It means that only through the process of motivating and funding university - business activities we can archieve better economic results in the future. Such mutual relations help to born new ideas and bring innovative technologies into the industry. Year to year, realizing one contry's direction of the certain strategy and vision, gives good results. Strategic goals should be estimated in regard with R\&D funding in every country.

In comparison, Lithuania should pay more attention to R\&D and investments into TT and innovation activities to reach its strategy and have performance results of R\&D funding - 1,9\% GDP. Investing more, Lithuania would have higher rank than 22 (group 6). On the other hand, the Latvia is also the leader from the back (total rank is 26), and Estonia is 18-th. So, the best performance results in Baltics have Estonia, second - Lithuania, and Latvia - 3-rd.

Comparring higher education sector, Estonia is funded the most (rank 15), Lithuania (rank 19) and Latvia (rank 22). If we see govenrment support for Baltics, it is quite near: Estonia (rank 22), Lithunia (rank 24), Latvia (rank 25). Busines sector: Estonia (rank 17), Lithunia (rank 24), Latvia (rank 25). We see that business sector in Estonia invest much more into R\&D than Lithunia and Latvia.

Portugal, Cyprus, United Kingdom, Italy, France and Finland are the most active in support private non-profit sector for R\&D activities. While Spain has the middle performance results from all 4 analyzed sectors in comparison with other countries.

Bulgaria, Romania and Malta have the lowest expenditures performance values in comparison with other European countries, and this could be related to the quite low economic development rate and low funding rate for R\&D.

\section{References}

Aghdaie, M. H.; Zolfani, S. H.; Zavadskas, E. K. 2013. Market segment evaluation and selection based on application of fuzzy AHP and COPRAS-G methods, Journal of Business Economics and Management 14(1): 213-233. https://doi.org/10.3846/16111699.2012.721392

Bausys, R.; Zavadskas, E. K.; Kaklauskas, A. 2015. Application of neutrosophic set to multicriteria decision making by COPRAS, Economic Computation \& Economic Cybernetics Studies \& Research 49(2): 84-98.

Chatterjee, P.; Athawale, V. M.; Chakraborty, S. 2011. Materials selection using complex propoptional assessment and evaluation of mixed data methods, Matherials and Design 32(2): 851-860. https://doi.org/10.1016/j.matdes.2010.07.010

European commission. 2016. Europe 2020 [online], [cited 17 February 2017]. Available from Internet: http://ec.europa.eu/eu2020/pdf/COMPLET\%20EN\%20BARROSO\%20\%20\%20007\%20-\%20Europe\%202020\%20-\%20EN\%20version.pdf

Eurostat. 2017. Science, technology and digital society. Research and development. R\&D expendidture on national and regional level [online], [cited 17 February 2017]. Available from Internet: http://ec.europa.eu/eurostat/data/database

Ghorabaee, M. K.; Amiri, M.; Sadaghiani, J. S.; Goodarzi, G. H. 2014. Multiple criteria group decision-making for supplier selection based on COPRAS method with interval type-2 fuzzy sets, The International Journal of Advanced Manufacturing Technology 75(5-8): 1115-1130. https://doi.org/10.1007/s00170-014-6142-7

Ginevicius, R. 2008. Normalization of quantities of various dimensions, Journal of Business Economics and Management 9(1): 7986. https://doi.org/10.3846/1611-1699.2008.9.79-86

Hashemkhani Zolfani, S.; Bahrami, M. 2014. Investment prioritizing in high tech industries based on SWARA-COPRAS approach, Technological and Economic Development of Economy 20(3): 534-553. https://doi.org/10.3846/20294913.2014.881435

Kaklauskas, A.; Zavadskas, E. K.; Naimaviciene, J.; Krutinis, M.; Plakys, V.; Venskus, D. 2010. Model for a complex analysis of intelligent built environment, Automation in construction 19(3): 326-340. https://doi.org/10.1016/j.autcon.2009.12.006

Kaklauskas, A.; Zavadskas, E. K.; Raslanas, S.; Ginevicius, R.; Komka, A.; Malinauskas, P. 2006. Selection of low-e windows in retrofit of public buildings by applying multiple criteria method COPRAS: a Lithuanian case, Energy and Buildings 38(5): 454-462. https://doi.org/10.1016/j.enbuild.2005.08.005

Koçak, H.; Çilingirtürk, A. M.; Kistik, V. 2017. The ranking analysis of the petroleum and related products'companies, Proceedings, of the $9^{\text {th }}$ MAC 2017, 73.

Kracka, M.; Brauers, W. K. M.; Zavadskas, E. K. 2010. Ranking heating losses in a building by applying the MULTIMOORA, Engineering Economics 21(4): 352-359.

Liou, J. J.; Tamošaitienė, J.; Zavadskas, E. K.; Tzeng, G. H. 2016. New hybrid COPRAS-G MADM Model for improving and selecting suppliers in green supply chain management, International Journal of Production Research 54(1): 114-134. https://doi.org/10.1080/00207543.2015.1010747

Mousavi-Nasab, S. H.; Sotoudeh-Anvari, A. 2017. A comprehensive MCDM-based approach using TOPSIS, COPRAS and DEA as an auxiliary tool for material selection problems, Materials \& Design 121: 237-253. https://doi.org/10.1016/j.matdes.2017.02.041

Mulliner, E.; Malys, N.; Maliene, V. 2016. Comparative analysis of MCDM methods for the assessment of sustainable housing affordability, Omega 59: 146-156. https://doi.org/10.1016/j.omega.2015.05.013

National Progress Programme for Lithuania for the period 2014-2020 [online], 2017 [cited 17 February 2017]. Available from Internet: https://rio.jrc.ec.europa.eu/en/library/national-progress-programme-lithuania-period-2014-2020

Nguyen, H. T.; Dawal, S. Z. M.; Nukman, Y.; Aoyama, H.; Case, K. 2015. An integrated approach of fuzzy linguistic preference based AHP and fuzzy COPRAS for machine tool evaluation, PloS one 10(9): e0133599. https://doi.org/10.1371/journal.pone.0133599 
Organ, A.; Yalcin, E. 2016. Performance evaluation of research assistants by Copras method, European Scientific Journal ESJ 12(10) SPECIAL edition: 102-109.

Pitchipoo, P.; Vincent, D. S.; Rajini, N.; Rajakarunakaran, S. 2014. COPRAS decision model to optimize blind spot in heavy vehicles: a comparative perspective, Procedia Engineering 97: 1049-1059. https://doi.org/10.1016/j.proeng.2014.12.383

Podvezko, V. 2011. The comparative analysis of MCDA methods SAW and COPRAS, Engineering Economics 22(2): 134-146. https://doi.org/10.5755/j01.ee.22.2.310

Popovic, G.; Stanujkic, D.; Stojanovic, S. 2012. Investment project selection by applying copras method and imprecise data, Serbian Journal of Management 7(2): 257-269. https://doi.org/10.5937/sjm7-2268

Rezazadeh, M. H.; Sancholi, B.; Rad, S. S.; Feyzabadi, A. N.; Kadkhodaei, M. 2017. Ranking of Zahedan's five districts in order to fulfill the creative city, Journal of History Culture and Art Research 6(1): 703-719. https://doi.org/10.7596/taksad.v6i1.776

Rivera, E. D.; Fajardo, C. A.; Ávila, A. J.; Ávila, C. F.; Martinez-Gómez, J. 2017. Material selection of induction cookware based on multi criteria decision making methods (MCDM), Revista Técnica Energía 13.

Sen, D. K.; Datta, S.; Mahapatra, S. S. 2017. Extension of TODIM for decision making in fuzzy environment: a case empirical research on selection of industrial robot, International Journal of Services and Operations Management 26(2): 238-276. https://doi.org/10.1504/IJSOM.2017.081492

Statistics Lithuania. 2016. Mokslo tiriamoji veikla 2015 m. [online], [cited 17 February 2017]. Available from Internet: https://osp.stat.gov.lt/informaciniai-pranesimai?articleId=4716840

Tavana, M.; Momeni, E.; Rezaeiniya, N.; Mirhedayatian, S. M.; Rezaeiniya, H. 2013. A novel hybrid social media platform selection model using fuzzy ANP and COPRAS-G, Expert Systems with Applications 40(14): 5694-5702. https://doi.org/10.1016/j.eswa.2013.05.015

Tupenaite, L.; Zavadskas, E. K.; Kaklauskas, A.; Turskis, Z.; Seniut, M. 2010. Multiple criteria assessment for built and human environment, Journal of Civil Engineering and Management 16(2): 257-266. https://doi.org/10.3846/jcem.2010.30

Turskis, Z.; Zavadskas, E. K.; Peldschus, F. 2009. Multi-criteria optimization system for decision making in construction design and management, Engineering Economics (1): 7-17.

Xue, Y. X.; You, J. X.; Zhao, X.; Liu, H. C. 2016. An integrated linguistic MCDM approach for robot evaluation and selection with incomplete weight information, International Journal of Production Research 54(18): 5452-5467. https://doi.org/10.1080/00207543.2016.1146418

Zavadskas, E. K.; Kaklauskas, A. 1996. Multicriteria evaluation of building (Pastatų sistemotechninis ịvertinimas). Vilnius: Technika.

Zavadskas, E. K.; Kaklauskas, A.; Sarka, V. 1994. The new method of multi-criteria complex proportional assessment of projects, Technological and Economic Development of Economy 1(3): 131-139.

Zavadskas, E. K.; Turskis, Z.; Kildiene, S. 2014a. State of art surveys of overviews on MCDM/MADM methods, Technological and Economic Development of Economy 20(1): 165-179. https://doi.org/10.3846/20294913.2014.892037

Zavadskas, E. K.; Turskis, Z.; Kildiene, S. 2014b. State of art surveys of overviews on MCDM/MADM methods, Technological and Economic Development of Economy 20(1): 165-179. https://doi.org/10.3846/20294913.2014.892037

Zavadskas, E. K.; Turskis, Z.; Tamosaitiene, J.; Marina, V. 2008a. Selection of construction project managers by applying COPRAS-G method, Computer Modelling and New Technologies 12(3): 22-28.

Zavadskas, E. K.; Kaklauskas, A.; Turskis, Z.; Tamosaitiene, J. 2008b. Contractor selection multi-attribute model applynig COPRAS method with grey interval numbers, in $20^{\text {th }}$ International Conference/Euro Mini Conference on Continuous Optimization and Knowledge-Based Technologies (EurOPT 2008), 20-23 May 2008, Neringa, Lithuania, 241-247.

Zavadskas, E. K.; Kaklauskas, A.; Turskis, Z.; Tamosaitiene, J.; Kalibatas, D. 2008c. Assessment of indoor environment applynig COPRAS method with attributes determined in intervals, in $7^{\text {th }}$ International Conference on Environmental Engineering, 22 23 May 2008, Vilnius, Lithuania, 1-3: 907-912.

Zolfani, S. H.; Pourhossein, M.; Yazdani, M.; Zavadskas, E. K. 2017. Evaluating construction projects of hotels based on environmental sustainability with MCDM framework, Alexandria Engineering Journal (13 January 2017). http://dx.doi.org/10.1016/j.aej.2016.11.002 